\title{
REFLEKSI PERAN PEREMPUAN DALAM NOVEL INDONESIA 1900-2000
}

\author{
Else Liliani dan Esti Swatika Sari \\ Fakultas Bahasa dan Seni Universitas Negeri Yogyakarta \\ e-mail: else_uny@yahoo.com
}

\begin{abstract}
This study aims to describe women's roles, problems, and ways to solve the problems reflected in Indonesian novels in the period of 1900-2000. The data sources were 20 top novels published in that period. The data were collected through reading and analyzed by relating them to several elements as their contexts and using the analytical construct in the feminist literary criticism. The results are as follows. First, women's public roles include their participation in the movements, education, and business and their domestic roles are as wife and mother. Second, their domestic problems are related to psychological problems, nationality, gender construction, domestic violence, and financial dependence. Third, the problems result from differences in nationality, society's patriarchal culture, religious interpretation, gender construction, politics, and financial dependence. Fourth, the characters' attitudes to the problems are in the form of submission, opposition, and escapism.
\end{abstract}

Keywords: women's roles, public and domestic roles, gender construction

\section{PENDAHULUAN}

Dalam perkembangannya, perjuangankaumperempuanIndonesiamengalami perubahan. Dimulai dengan perjuangan melawan penjajah sampai pada isu pendidikan dan persamaan hak bagi perempuan. Satu per satu organisasi perempuan muncul dengan ideologinya masing-masing, misalnya Aisjijah (1917) yang merupakan organisasi Islam, Jong Java (1915) yang bersifat nonreligius, Poetri Boedi Soedjati (1919) nonreligius yang merupakan seksi wanita Pemoeda Indonesia, Wanita Oetomo (1921) nonreligius dan nasionalis, Wanita Kentjono (1928) nonreligius dan tujuan-tujuannya sangat konservatif. Organisasi tersebut pun berkembang pesat dengan mempunyai cabang di berbegai daerah, misalnya Aisjijah pada tahun 1930 mempunyai 5000 ribu anggota dengan 47 cabang dan 50 kelompok, atau Wanita Oetomo yang pada tahun 1939 dinyatakan telah memiliki 290 angota dan sekitar 10 cabang.
Dalam pandangan feminisme, pembagian peran antara laki-laki dan perempuan dapat dipetakan menjadi dua macam. Pertama, karena karakteristik psikologis perempuan (nature). Kedua, karena konstruk sosial (nurture). Paham teori nature beranggapan bahwa perbedaan psikolohis antara lelaki dan perempuan disebabkan oleh faktor biologis, sedangkan paham teori nurture beranggapan bahwa perbedaan peran tersebut berangkat dari proses belajar dari lingkungan. John Stuart Mill dalam The Subjection of Women berpendapat bahwa sifat kewanitaan adalah hasil dari konstruksi masyarakat melalui sistem pendidikan. Usaha untuk membedakan peran mereka merupakan tindakan politik yang terencanakan (Mills, 1929:9).

Teori nature ini terutama berkembang atas dasar pemikiran psikoanalisa Sigmund Freud yang berpendapat bahwa karena adanya penis enoy, perempuan sejak kecil telah memahami bahwa dalam diri mereka terdapat ke- 
kurangan, dibandingkan dengan anak laki-laki. Karenanya, muncul inferioritas dalam diri mereka. Sewaktu dewasa, keinginan memiliki kelamin laki-laki berubah menjadiu keinginan memiliki bayi. Kate Millet membantah teori ini, dan mengatakan bahwa teori Freud ini justru mendomestikkan perempuan karena Freud berpendapat bahwa perempuan yang baik adalah perempuan yang menjalankan fungsinya sebagai mesin reproduksi atau pengembang keturunan.

Teori nurture dikembangkan oleh paham Fungsionalis dan Marxis. Dalam paham teori fungsionalis, pembagian peran antara laki-laki dan perempuan dalam masyarakat pada hakikatnya merupakan pembagian secara seksual. Paham fungsionalis lebih banyak membicarakan peran perempuan dalam keluarga. Bagi paham fungsionalis, fungsi keluarga selalu sama, yakni hubungan seksual yang mendapat pengesahan masyarakat, fungsi ekonomi, fungsi pengembangan keturunan, dan fungsi pendidikan bagi anak yang dilahirkan dalam keluarga tersebut (Mardock via Budiman, 1982:15). Engels berpendapat bahwa pembagian peran secara seksual memang memungkinkan masing-masing pihak (laki-laki dan perempuan) mendapakan keuntungan darinya. Namun, ini membuat laki-laki lebih bisa memanfaatkan dan menjadikannya sebagai kesempatan untuk mengembangkan kekuasaannya.

Ada berbagai sumber yang dapat menjadi acuan untuk melihat bagaimana perkembangan peran perempuan, antara lain dengan sastra. Sastra bisa dikatakan sebagai "dokumen" (Wellek dan Warren, 1990:87). Sastra merekam sejarah dengan caranya yang unik, yakni merekam realitas di masyarakat dengan membuat narasi terhadapnya (Damono, 1979:35). Atau dengan kata lain, sastra merekam kenyataan dan merepresen- tasikannya kembali dengan cara yang menyenangkan dan menghibur (Teeuw, 2003:89).

Penelitian ini mengkaji peran perempuan seperti yang terefleksi dalam novel-novel di Indonesia sejak 1900 hingga 2000. Dengan melihat karya-karya puncak di setiap dekadenya, diharapkan penelitian ini dapat memberikan gambaran mengenai bagaimana perkembangan peran perempuan dalam masyarakat. Selain itu, penelitian ini hendak mengupas problematika yang dialami perempuan dalam menjalankan perannya. Hasil penelitian ini diharapkan dapat disumbangkan sebagai salah satu bahan untuk menyusun atau membantu merekonstruksi sejarah perkembangan peran perempuan Indonesia.

Penelitian-penelitian yang bertujuan membahas peran perempuan di Indonesia sejak tahun 1900an hingga sekarang perlu dilakukan. Selain merekonstruksi sejarah perkembangannya, penelitian-penelitian itu dapat dimanfaatkan untuk mengenalkan dan menanamkan peran penting perempuan bagi kehidupan kepada generasi muda. Dengan mengenalkan nilai perempuan kepada masyarakat maupun generasi muda, diharapkan muncul sikap menghargai dan menghormati keberadaan perempuan. Sehingga, tidak ada lagi pandangan miring bahwa keberadaan perempuan hanya sekedar kanca wingking atau sekedar pelengkap saja, melainkan memilki peran yang penting dan menduduki posisi yang sama dengan lelaki.

Kritik sastra feminis merupakan salah satu upaya membaca dan memahami sastra dengan perspektif perempuan. Dengan kata lain, reading as a woman (Culler dalam Sugihastuti dan Suharto, 2002:5). Kritik sastra feminis tidak sama dengan (seorang) pengritik perempuan, atau kritik tentang perempuan, atau kri- 
tik terhadap seorang pengarang perempuan. Kritik sastra feminis adalah suatu kajian karya sastra yang mendasarkan pada pandangan feminisme yang menginginkan adanya keadilan dalam memandang eksistensi perempuan, baik sebagai penulis maupun dalam karyakarya sastranya (Djajanegara, 2000:15). Secara leksikal, feminisme merupakan gerakan kaum perempuan yang menuntut persamaan hak sepenuhnya antara kaum perempuan dan laki-laki. Persamaan itu meliputi semua aspek kehidupan, baik dalam bidang politik, ekonomi, maupun sosial budaya. Dalam kritik sastra feminis, studi sastra mengarahkan fokus analisisnya pada perempuan.

Keberadaan kritik sastra feminis ini tidak bisa dipisahkan dari adanya gerakan feminis. Gerakan feminis sendiri muncul karena adanya upaya untuk membebaskan tubuh perempuan dari berbagai pasungan yang diciptakan dan dan senantiasa diinternalisasikan dalam budaya patriarki melalui pembodohan, pemasungan kebebasan perempuan, dan penyangkalan diri secara sistematis melalui lembaga ekonomi, sosial, dan politik (Lie, 2005:48). Budaya patriarkat di sini merupakan sebuah sistem sosial yang mengatur relasi antara perempuan dan laki-laki sedemikian rupa sehingga menyangkal kebebasan perempuan sebagai subjek dan keterbatasan laki-laki sebagai objek. Masalah feminisme juga tidak bisa terlepas dari masalah budaya dan etnisitas Brooks (2005:25)

Menurut Fakih (dalam Bainar, 1998:27), bentuk-bentuk ketidakadilan yang dialami oleh kaum perempuan antara lain marginalisasi atau proses pemiskinan ekonomi, subordinasi atau adanya anggapan tidak penting dalam suatu keputusan politik, stereotyping dan dikriminasi atau pelabelan negatif, kekerasan (violence) baik fisik maupun nonfisik, dan bekerja lebih panjang dan lebih banyak (double burden). Perjuangan persamaan hak dan kewajiban antara kaum lelaki dan perempuan melalui perspektif feminis dalam suatu karya bisa tercermin dalam konflik. Dalam suatu permasalahan yang dialami oleh tokoh, maka akan terlihat refleksi dari adanya pemikiran dan pemahaman tentang (tokoh) perempuan. Konflik yang terdapat dalam suatu karya sastra merupakan gambaran hubungan kausalitas antara apa yang tengah dan akan terjadi pada perempuan.

\section{METODE}

Penelitian ini dilakukan dengan memanfaatkan pustaka sebagai objek kajiannya. Oleh karena itu, jenis penelitian ini adalah deskriptif kualitatif. Penelitian ini mencoba mendeskripsikan dan menganalisis peran, problematika, serta sikap perempuan dalam mengatasi problematika yang muncul terkait perannya dalam masyarakat. Setelah data-data yang terkait dengan rumusan masalah penelitian itu ditemukan, data tersebut dianalisis secara kualitatif dengan melakukan pemaknaan terhadapnya.

Untuk mengkaji peran perempuan yang terefleksi dalam novel-novel Indonesia 1900-2000, penelitian ini menggunakan kurang lebih 20 novel karya puncak yang akan dipilih sebagai sumber data. Yang dimaksud dengan novel puncak adalah novel yang dinilai memiliki keunikan dan berbeda dalam hal estetika dan ekstra-estetik dibandingkan novel-novel yang terbit pada masanya seperti yang dikemukakan oleh Umar Junus dalam bukunya yang berjudul Perkembangan Novel-novel Indonesia (1974) dan Ringkasan dan Ulasan Novel Indonesia Modern karya Maman S Mahayana, Oyon Sofyan, dan Achmad Dian (2007). Karya-karya yang akan dikaji disajikan dalam tabel 1. 
Tabel 1 Karya-karya yang Dijadikan Sumber Data

\begin{tabular}{|c|c|c|c|}
\hline No. & Periode & Judul Karya & Pengarang \\
\hline \multirow[t]{2}{*}{1.} & 1990-an & Boenga Roos dari Tjikembang & Kwee Tek Hoay \\
\hline & & Nyai Soemirah & Thio Tjin Boen \\
\hline \multirow[t]{2}{*}{2.} & 1910-an & Student Hidjo & Marco Martodikromo \\
\hline & & Hikayat SIti Mariah & Haji Mukti \\
\hline \multirow[t]{2}{*}{3.} & 1920-an & Siti Nurbaya & Marah Rusli \\
\hline & & Azab dan Sengsara & Merari Siregar \\
\hline \multirow[t]{2}{*}{4.} & 1930-an & Belenggu & Armijn Pane \\
\hline & & Layar Terkembang & Sutan Takdir Alisjahbana \\
\hline 5. & 1940-an & Atheis & Aoh Kartamohardja \\
\hline \multirow[t]{2}{*}{6.} & 1950-an & Perburuan & Pramoedya Ananta Toer \\
\hline & & Jalan Tak Ada Ujung & Mochtar Lubis \\
\hline 7. & 1960-an & Kemarau & AA Navis \\
\hline \multirow[t]{2}{*}{8.} & 1970-an & Pada Sebuah Kapal & NH Dini \\
\hline & & Khotbah di Atas Bukit & Kuntowijoyo \\
\hline \multirow[t]{2}{*}{9.} & 1980-an & Canting & Arswendo Atmowiloto \\
\hline & & Ronggeng Dukuh Paruk & Ahmad Tohari \\
\hline \multirow[t]{2}{*}{10.} & 1990-an & Saman & Ayu Utami \\
\hline & & Para Priyayi & umar Kayam \\
\hline \multirow[t]{2}{*}{11.} & 2000-an & Perempuan Berkalung Sorban & Abidah EL Khalieqy \\
\hline & & Tanah Tabu & Anindita S Thayf \\
\hline
\end{tabular}

Teknik pengumpulan data dilakukan dengan teknik baca dan catat. Analisis data dilakukan dengan teknik deskriptif kualitatif. Data-data yang telah dikumpulkan berdasarkan rumusan permasalahan. Setelah dikumpulkan, data tersebut diinterpretasikan, kemudian dilakukan inferensi. Inferensi digunakan untuk menginterpretasikan dan menyimpulkan hasil penelitian sesuai dengan permasalahan penelitian. Penelitian ini menggunakan validitas semantik untuk mengukur kesesuaian makna data yang ditemukan dengan rumusan masalah yang diajukan. Proses analisis data diuji dengan validitas konstruk yaitu dengan melakukan analisis terhadap keterkaitan antardata dengan berbagai unsur yang menjadi konteksnya, yang dalam kasus penelitian ini mendasarkan pada konstruk analisis kritik sastra feminis. Selanjutnya, reliabilitas hasil penelitian diuji dengan teknik intraratter dan interrater. Peneliti juga melakukan diskusi dengan rekan sejawat yang berkompeten sesuai dengan fokus penelitian.

\section{HASIL DAN PEMBAHASAN}

Peran Perempuan yang Terefleksi dalam Novel-novel Indonesia 19002000

Novel-novel yang dikaji dalam penelitian ini menggambarkan keberagaman peran perempuan. Ada yang menggambarkan perempuan di bidang publik saja, domestik saja, dan ada pula yang menggambarkan di antara 
keduanya. Peran-peran perempuan di bidang publik sebenarnya telah ditemukan pada novel Indonesia periode 1900an, yakni pada karya Cerita Nyai Soemirah karya Thio Tjin Boen (1917). Tokoh Nyai Soemirah dalam novel karya Thio Tjin Boen ini memiliki akses untuk mendapatkan pendidikan karena dia adalah seorang keturunan bangsawan di Jawa Barat. Bahkan, pengarang memberikan gambaran bahwa Nyai Soemirah adalah perempuan yang cerdas dan berani, karena sanggup menentang dominasi dari Ardi (seorang pembunuh) kemudian melaporkannya ke Landraad (pengadilan Eropa). Peran perempuan di bidang pendidikan juga ditemui dalam novel Student Hidjo, seperti yang ditunjukkan oleh Raden Ajeng Wungu. Namun, Raden Ajeng Wungu ini juga bukan perempuan sembarangan, dia adalah keturunan bangsawan. Peran ini masih berlangsung pada periode 1920an, dengan tampilnya tokoh Siti Nurbaya dalam novel Siti Nurbaya yang berhasil mengenyam pendidikan (meskipun tingkat pendidikannya masih harus ada di bawah lelaki) karena keturunan bangsawan. Akses perempuan di bidang pendidikan paling banyak ditemukan karena faktor keturunan. Tokoh Annisa dalam novel Perempuan Berkalung Sorban juga mendapatkan akses pendidikan karena orang tuanya adalah seorang kyai (orang terpandang).

Mulai periode 1930an, akses perempuan di bidang pendidikan tidak hanya semata-mata didasarkan pada keturunan bangsawan, melainkan oleh factor ekonomi. Seorang Tuti dalam novel Layar Terkembang dan Kartini dalam novel Atheis adalah contohcontoh tokoh perempuan yang berhasil mengenyam pendidikan karena berasal dari keluarga yang ekonominya mampu. Demikian juga pada tokoh Fatimah dalam novel Jalan Tak Ada Ujung dan tokoh Sri dalam Pada Sebuah Kapal.
Peran perempuan di bidang publik lainnnya juga ditemukan dalam tokoh Popi dalam Khotbah di Atas Bukit dan Srintil dalam Ronggeng Dukuh Paruk. Namun, sayangnya, peran mereka adalah peran-peran yang sebenarnya adalah bentuk dominasi dari penguasaan lelaki di bidang publik. Popi dan Srintil sama-sama memiliki peran sebagai penghibur bagi laki-laki. Mereka diterima di dunia laki-laki, namun hanya sebatas menghibut. Pada hakikatnya, derajat mereka tetap sama rendahnya. Sedangkan peran perempuan di bidang publik sekaligus domestik dapat ditemukan dalam novel Tjerita Nyai Soemirah, Student Hidjo, Siti Nurbaya, Belenggu, Layar Terkembang, Atheis, Jalan Tak Ada Ujung, Pada Sebuah Kapal, Khotbah di Atas Bukit, Canting, Ronggeng Dukuh Paruk, serta Perempuan Berkalung Sorban.

Peran perempuan di bidang domestik biasanya berkaitan dengan kerja-kerja kerumahtanggaan, seperti (terutama) melayani suami, merawat anak dan suami, mengerjakan beberapa pekerjaan rumah tangga (memasak, membersihkan rumah, mencuci, dst). Gambaran mengenai perempuan yang intens mengerjakan perannya di bidang domestik dapat ditemui dalam novel Canting karya Arswendo Atmowiloto.

"Namun hal itu jarang. Bu Bei pasti ke kamar mandi. Bu Bei sudah menyediakan air hangat yang dijerang di atas kompior. Tinggal membawa dan menuangkan ke bak ember. Lalu menuangkan air dingin dari bak kamar mandi yang besar sekali. Menyentuh denga tangannya untuk merasakan bahwa airnya vukup hangat -tidak terlalu dingin dan tidak terlalu panas. Ujung kuku $\mathrm{Bu}$ Bei bisa mengetahui persis suam yang dikehendaki Pak Bei. Seperti juga kepekaan Bu Bei bisa mengetahui handuk apa yang dipilih saat itu, kain sarung tenun yang mana, 
atauopn kaus dan piyama apa yang dipilih. Semua telah dipersiapkan, digantungkan di dinding pintu kamar mandi. Juga obat keramas yang dibuat sendiri oleh tangannya, dari merang padi. Sabun kesukaan Pak Bei pun tak pernah tinggal sedikit. Bu Bei sangat paham bahwa suaminya tak menyukai sabun yang kecik, karena suka meloncat kalau dipegang. Atau sandal pilihannya untuk dikenakan di dalam rumah. Pak Bei paling benci dengan sandal jepit. Yang dianggap sandal paling kurang ajar, paling tidak berbudaya, paling kampungan. Pak Bei menyebutnya sebagai "sandal abrik", istilah barbar, tak mengenal komnpromi sama sekali. Semua istilah yang dikaitkan dengan "pabrik" memunyai konotasi yang tidak berbudaya,tidak sopan, tidak etis. Oleh Bu Bei ini diterjemahkan sebagai aturan kepada anakanaknya. (Atmowiloto, 1987:32 - 33).

Peran perempuan di bidang publik sekaligus domestik yang begitu besar sebenarnya adalah bentuk double burden atau beban ganda yang biasa dialami oleh perempuan-perempuan pekerja. Tidak jarang, beban ganda ini nantinya juga dapat menimbulkan masalah di rumah tangganya, seperti yang dialami oleh Tini dalam novel Belenggu.

Peran perempuan di bidang publik ditunjukkan oleh keaktifan Tuti dalam bergabung dengan Puteri Sedar. Peran perempuan di bidang publik tak hanya ditemukan di dunia pendidikan, namun juga di dunia perekonomian dan jurnalisme. Seorang Bu Bei dalam novel Canting menjalankan roda perusahaan keluarganya. Demikian pula dengan Laila dan Yasmin dalam novel Saman. Peran perempuan di bidang sosial atau LSM yang melindungi perempuan, dapat ditemui dalam novel Perempuan
Berkalung Sorban karya Abidah el Khalieqy. Namun, peran Annisa (tokoh utama dalam novel Perempuan Berkalung Sorban) untuk mendapatkan kebebasannya dari Samsuddin, suaminya, bukanlah suatu hal yang mudah. Annisa menjadi aktif ketika sudah bercerai dari suami pertamanya, untuk kemudian menikah dengan Khudori, lelaki yang sebenarnya dicintainya.

\section{Permasalahan yang Dialami oleh Perempuan}

Karena tokoh-tokoh perempuan dalam keduapuluh novel yang dikaji sebagian besar lebih banyak bergerak dalam bidang domestik, maka permasalahan yang ditemuinya pun banyak yang berkaitan dengan urusan rumah tangga. Permasalahan yang paling banyak ditemui adalah permasalahan terkait dengan psikologis $(37,5 \%)$, kekerasan dalam rumah tangga $(28,125 \%)$, konstruksi gender di masyarakat (18, $75 \%)$, kebangsaan $(9,375 \%)$, dan politik serta ketergantungan ekonomi (masingmasing sebesar 3, 125\%).

Perasaan cinta tokoh perempuan kepada pasangan mereka masing-masing adalah sumber permasalahan yang banyak ditemui. Tokoh Marsiti, Siti Mariah, dan Soemirah, misalnya. Permasalahan mereka hamper sama. Terjebak pada cinta kepada lelaki asing, kemudian harus berpisah secara paksa. Dalam kasus ini, persoalan cinta mereka berbalut dengan persoalan kebangsaan.

Berikut adalah contoh kutipan dari tokoh Siti Mariah dalam novel $\mathrm{Hi}_{-}$ kayat Siti Mariah yang mengalami permasalahan terkait dengan statusnya sebagai nyai (gundik) dari seorang Eropa bernama Henry Dam.

"Ya, Allah, Henri, jantung hatiku. Memang, Henri, saya juga kuatir. Setelah saya dengar maksudmaksud nyonya besarm hatiku jadi kacau, tiba-tiba, kuatir, berat untuk 
dirasa. Saya dikehendaki dibuang, diceraikan dari suami, dipisahkan dari anak. Oo, Gusti Allah, apa guna hidup di dunia ini lagi? Seribu kali lebih baik hanyut di Kali Serayu. Biar kuserahkan jiwaku pada Gusti Allah. Ya Allah, Henriku. Kau tahu sendiri betapa besar cintaku padamu, terutama pada Ari. Kalau cinta boleh dibandingkan dengan dunia, bisa dikatakan cintaku sebesar gunung, sedang dunia Cuma sebesar semut. Cinta sebesar itu mau dibikin jadi cair, mau dimusnahkan, dihancurkan? O, Allah. Mustahil kalau Gusti Allah tak hendak melindungi. Ya, Henri, ya bapakku. Saya merasa waswas dalam hati. Hanya bisa memuji pada Tuhan semoga diberi keselamatan seperti yang sudah-sudah. Ya, Ari, anakku, mama mesti terpisah dari nyoo? Oo Allah, jatuh gila tentu mamamu ini..." (hlm. 152-153)

Temuan yang cukup menarik dari penelitian ini adalah masih terbelenggunya perempuan oleh persoalan psikologis, meski dia adalah seorang yang maju dan berpendidikan tinggi pada masanya. Fenomena ini banyak ditemui dalam novel berjudul Belenggu, Layar Terkembang, Jalan Tak Ada Ujung, dan Pada Sebuah Kapal.

Munculnya permasalahan-permasalahan psikologis dalam perempuan-perempuan yang eksis di bidang publik dan domestik menunjukkan bahwa perempuan-perempuan dalam novel yang ditemukan itu masih dicitrakan sebagai perempuan yang lemah. Mereka boleh jadi telah mendapat pendidikan, akses yang sama dengan lelaki, namun persoalan cinta membuat mereka menjadi jatuh juga. Akhirnya, stereotipisasi perempuan sebagai kaum yang lemah kembali diperkuat dalam novel-novel ini.
Selain persoalan psikologis yang menonjol, permasalahan kekerasan dalam rumah tangga (KDRT) tampaknya adalah suatu permasalahan yang sudah sejak dahulu dialami oleh perempuan. Permasalahan KDRT (terutama fisik) dapat ditemukan pada novel periode 1920an hingga 2000an. Pada periode 2000an, ada Siti Nurbaya yang mendapat perlakukan keji dari suaminya, Datuk Maringgih yang cemburu kepadanya. Siti Nurbaya hendak diracun oleh suaminya sendiri.

Pada periode 1940an, ditemukan pula bentuk kekerasan dalam rumah tangga, yang dialami oleh tokoh Kartini. Lagi-lagi, pelakunya tak lain adalah suaminya sendiri. Dan penyebabnya, adalah Hasan yang terbakar oleh api cemburu kepada isteri dan sahabatnya.

Bentuk pelecehan seksual yang dilakukan oleh suami dapat ditemui dalam novel berjudul Perempuan Berkalung Sorban. Kekerasan fisik oleh suami kepada istri juga ditemukan dalam novel berjudul Tanah Tabu. Novel ini adalah novel pemenang sayembara Dewan Kesenian Jakarta. Novel ini bersettingkan tanah Papua. Seperti halnya perempuan lainnya, tokoh Mama Helda juga mengalami kekerasan dari suaminya sendiri. Bahkan, terkadang, anak-anak mereka juga menjadi korban KDRT oleh papanya.

Selain kekerasan dalam rumah tangga (KDRT), permasalahan yang dialami oleh tokoh perempuan dalam novel-novel yang dikaji adalah permasalahan yang terkait dengan konstruksi gender yang dibentuk oleh masyarakat. Masyarakat yang ditemui dalam novelnovel yang dianalisis adalah masyarakat yang tipenya patriarchal. Beberapa aturan pembagian kerja didasarkan pada perbedaan seksual. Jika lelaki mencari nafkah, maka tugas perempuan adalah di rumah.

Perempuan adalah gambaran makhluk serupa malaikat yang diberi 
wewenang dan tanggung jawab untuk mengurusi rumah tangga. Oleh karena itu, tanggung jawabnya terhadap keluarga sangatlah besar. Tak heran, mengapa perempuan menjadi tak berharga lagi ketika dia mulai meninggalkan tugas-tugasnya sebagai seorang ibu atau isteri. Persoalan-persoalan terkait dengan konstruksi gender cukup banyak ditemukan. Konstruksi gender menjadi sumber permasalahan, terutama dalam novel Layar Terkembang, Saman, dan Perempuan Berkalung Sorban.

Konstruksi gender umumnya berupa paradigm yang dibangun oleh masyarakat mengenai tugas-tugas perempuan. Perempuan dalam konstruk yang ditemukan, adalah memiliki tugas merawat anak dan suami, menyenangkan hati suami, tunduk dan patuh pada perintah suami. Oleh karena itu, semaju, semodern apapun perempuan, jika belum menjalankan tugasnya, maka hidupnya belumlah dapat dikatakan sempurna. Gambaran itu dipertegas oleh Sutan Takdir Alisjahbana dalam novelnya yang berjudul Layar Terkembang.

Konstruk budaya patriarki yang membentuk dan menempatkan lelaki sebagai kelas yang mendominasi adalah sumber permasalahan, yang akhirnya merembet ke mana-mana. Karena pemikiran ini, maka peran perempuan selaku isteri kadang tak ubahnya seperti pembantu bagi suaminya. Beberapa novel, malah justru menunjukkan bahwa kultur seperti itu menempatkan hubungan suami isteri menjadi hubungan majikan dan budak; lelaki sebagai majikan dan perempuan sebagai budaknya. Ini dapat ditemui dalam novel Tanah Tabu dan Perempuan Berkalung Sorban.

Dari beberapa uraian di atas, dapat disimpulkan bahwa permasalahan-permasalahan yang dialami oleh tokoh perempuan adalah permasalah- an yang tidak berdiri sendiri. Konstruk gender yang dibentuk oleh masyarakat membentuk kultur budaya yang akhirnya menempatkan relasi laki-laki dan perempuan menjadi subordinat atau tidak setara. Relasi yang tak seimbang ini secara tidak sadar menempatkan lelaki sebagai kelas pertama, dan perempuan sebagai kelas kedua. Penepatan perempuan sebagai kelas kedua menyebabkan munculnya konflik-konflik baru dalam diri perempuan, baik ketika dia belum berstatus sebagai isteri/ibu maupun sesudah menjadi isteri/ibu. Akhirnya, konflik-konflik psikologis atau konflik lainnya (ketergantungan ekonomi, kekerasan dalam rumah tangga) pun tak bisa dihindari. Terbukti, karena ikatan psikologis yang kuat antara lelaki dan perempuan, maka perempuan akan turut mendapatkan masalah dari lelaki yang dicintainya, seperti tokoh Ngaisah dalam Para Priyayi dan Ningsih dalam Perburuan.

\section{Penyebab Permasalahan yang Dialami oleh Perempuan}

Dari rumusan permasalahan kedua penelitian ini, didapatkan temuan bahwa permasalahan yang dialami oleh perempuan adalah permasalahanpermasalahan yang berkaitan dengan psikologis, perbedaan kebangsaan, konstruksi gender, kekerasan dalam rumah tangga, politik, serta ketergantungan ekonomi. Penyebab dari permasalahanpermasalahan tersebut di atas adalah perbedaan kebangsaan, kultur budaya, interpretasi agama, konstruksi gender, politik, dan ketergantungan ekonomi.

Dari sekian penyebab permasalahan, kultur budaya ternyata adalah penyebab permasalahan terbesar dari sekian permasalahan yang ada. Perempuan dalam hal ini adalah bagian dari system masyarakat. Kebetulan, masyarakat yang ada dalam novel-novel yang dianalisis adalah masyarakat yang 
patriarkis. Masyarakat patriarkis ini menempatkan perempuan sebagai kelas kedua.

Kultur masyarakat yang patriarkis juga menyebabkan perempuan yang meskipun sudah mendapatkan kesempatan untuk mengakses dunia publik akhirnya bertekuk lutut. Tokoh Tuti dalam Layar Terkembang dan Tini adalah Belenggu adalah gambaran perempuanperempuan modern. Namun, kemajuan mereka tidak diimbangi dengan kesuksesan terkait dengan ruang domestik yang dipersiapkan oleh masyarakat untuk mereka. Meski berhasil memasuki dunia publik, Tuti merasakan kekosongan dalam hidup karena dia membutuhkan cinta dari seorang lelaki. Tini tak berhasil membina rumah tangganya dengan Sukartono, suaminya. Tingkah lakunya sebagai perempuan modern, yang tidak biasa dengan wanta sejamannya membuat dia banyak mendapatkan cibiran.

Apa katanya tadi? Tentang perempuan sekarang? Perempuan sekarang hendak sama haknya dengan kaum laki-laki. Apa yang hendak disamakan. Hak perempuan ialah mengurus anak suaminya, mengurus rumah tangga. Perempuan sekarang Cuma meminta hak saja pandai. Kalau suaminya pulang dari kerja, benar dia suka menyambutnya, tetapi dia lupa mengajak suaminya duduk, biar ditanggalkannya sepatunya. Tak tahukah perempuan sekarang, kalau dia bersimpuh di hadapan suaminya akan menanggalkan sepatunya bukankah itu tanda kasih, tanda setia? Apa lagi hak perempuan, lain dari memberi hati pada laki-laki? (hlm. 17)

Kultur budaya yang menempatkan perempuan sebagai subaltern sebagai kelas yang terdominasi mem- buat perempuan banyak mengalami kekerasan dalam rumah tangga. Perempuan menjadi pihak yang pasif, banyak mengalami tekanan justru dari orang-orang terdekatnya, yakni suami. Tokoh Annisa dalam novel Perempuan Berkalung Sorban, misalnya. Annisa terdominasi oleh suaminya sendiri, Samsuddin. Dia mendapatkan perlakuan kasar dan pelecehan seksual dari suaminya. Namun, Annisa lebih memilih diam ketika menghadapi persoalan itu. Ini diperparah dengan pemanfaatan tafsir agama untuk terus mendominasi perempuan.

Ustad Ali mulai mensitir sebuah hadist yang diriwayatkan oeh seorang sahabat Nabi bernama Abdullah bin Mas'ud r.a yang berbunyi, "Perempuan mana saja yang diajak suaminya untuk berjimak lalu ia menunda-nunda hingga suaminya tertidur, maka ia akan dilaknat oleh Allah."...

"Bagaimana jika istrinya mengajak ke tempat tidur dan suami menunda-nunda hingga istri tertidur, apa suami juga dilaknat oleh Allah?"

Dengan tegas dan sedikit kaget yang berusaha ditutupinya, ustadz Ali ceat menyahut.

"Tidak. Sebab tak ada hadis yang menyatakan seperti itu. Lagipula mana ada seorang istri yang mengajak lebih dulu ke tempat tidur. Seorang istri biasanya pemalu dan bersikap menunggu." (hal.80)

Kultur budaya demikian juga menyebabkan Mariamin menanggung kekerasan dalam rumah tangga yang dilakukan oleh suaminya, Kasibun. Mariamin pun tak melakukan perlawanan yang berarti karena dia memiliki ketergantungan ekonomi. Ini diperparah dengan psikologis Kasibun yang suka 
cemburu. Perlakuan perempuan sebagai properti bagi suami sehingga menimbulkan sikap cemburu dari sang suami juga ditemukan dalam novel Atheis. Kartini adalah seorang perempuan yang terjun ke bidang politik. Kedekatannya dengan kawan-kawan lelakinya menyebabkan suaminya, Hasan, cemburu. Kartini dinilai lalai dalam menjalankan tugas-tugasnya sebagai seorang isteri. Hasan mencemburui kedekatannya dengan kawan seperjuangan, Anwar. Akibatnya, Hasan sering melakukan kekerasan terhadap Kartini.

Kultur budaya, interpretasi agama, serta ketergantungan ekonomi mendasari konstruk gender yang dibangun oleh masyarakat. Oleh karena fisik perempuan dinilai lemah, maka tugasnya selalu dikaitkan dengan tugas-tugas kerumahtanggaan, mengurus anak, mengurus suami. Oleh karena fisik-biologis perempuan yang memiliki payudara dan rahim, maka perempuan ditempatkan sebagai seorang calon ibu yang mesti merawat anak dan bersikap lembut. Karena pendomestifikasian, maka perempuan mengalami ketergantungan ekonomi terhadap suaminya. Sehingga, seringkali ini menjadi masalah dalam rumah tangga. Perempuan yang terlalu aktif di ruang publik menjadi masalah tersendiri, karena dengan demikian dia dinilai akan mengabaikan tugas-tugas kerumahtanggaannya.

\section{Cara Penyelesaian Masalah}

Menghadapi permasalahan-permasalahan yang dialami oleh tokoh perempuan, peneliti menemukan bahwa ada tiga cara yang umumnya ditemui dalam penelitian ini. Pertama, adalah eskapisme atau pelarian terhadap masalah. Kedua, pasrah atau tunduk terhadap permasalahan itu. ketiga, melakukan perlawanan.

Eskapisme terutama dilakukan oleh tokoh-tokoh perempuan yang merasa tak bisa melakukan perlawanan. Untuk melawan, dia tak berdaya. Namun untuk tunduk terhadap permasalahan itu, dia tak mau. Oleh karena itu, jalan satu-satunya yang dipilih oleh perempuan adalah lari dari permasalahan itu. Meskipun, hal ini sebenarnya juga bukan merupakan cara penyelesaian suatu masalah.

Tini adalah tokoh perempuan yang unik. Dia digambarkan maju, berani, dan eksis dengan pengetahuan dan cara hidupnya yang banyak terpengaruh oleh barat. Namun, pada akhirnya, Tini pun berhasil dikalahkan dan memilih untuk menyerah dan lari. Tono, suaminya yang lebih memilih Yah, serta cibiran dari masyarakat akan dirinya yang dinilai kelewatan batas membuat Tini lebih memilih untuk pergi dari Tono.

Tak banyak tokoh perempuan yang melakukan perlawanan. Mereka yang melakukan perlawanan biasanya berasal dari masyarakat kelas sosial tinggi, atau berpendidikan. Hal inilah yang Nampak pada novel Tjerita Nyai Soemirah, Perempuan Berkalung Sorban, Saman, Atheis, serta Perburuan. Tokoh Soemirah berani menentang dominasi lelaki (Arkum) dengan mengadukannya ke pengadilan. Tokoh Soemirah ini bukan tokoh perempuan biasa. Latar belakang pendidikan Belanda-nya, serta latar belakang sosial bangsawan yang dimilikinya memungkinkannya untuk menempuh jalur itu.

Berbeda dengan Soemirah, tokoh Annisa, Yasmin dan Laila, Kartini, serta Ningsih melakukan perlawanan lebih karena latar belakang pendidikannya. Annisa adalah seorang anak kyai yang cerdas. Sedangkan Yasmin dan Laila dibesarkan dalam keluarga yang kaya, sehingga akses pendidikan mereka pun tinggi. Ningsih adalah seorang guru dan anggota dari pergerakan perempuan. Latar belakang pengalaman, pendidikan, serta keberanian merekalah yang 
membuat tokoh-tokoh tersebut berani melakukan perlawanan.

Sikap pasrah, tunduk, menyerah terhadap permasalahan yang dialami perempuan menyebabkan mereka terbelenggu oleh permasalahan-permasalahan itu. Sikap seperti ini paling banyak ditemui dalam novel-novel yang dikaji, misalnya Canting, Kemarau, Student Hidjo, Siti Nurbaya, Azab dan Sengsara, Layar Terkembang, Tanah Tabu, Para Priyayi, Jalan Tak Ada Ujung, Pada Sebuah Kapal, Khotbah di Atas Bukit, dan Ronggeng Dukuh Paruk.

Sikap-sikap pasrah, menyerah, dan tunduk terhadap permasalahan umumnya terjadi pada perempuanperempuan yang tak memiliki latar belakang pendidikan, mengalami ketergantungan ekonomi, serta berada dalam tekanan masyarakat patriarkis yang sangat hebat. Tokoh Srintil dalam novel Ronggeng Dukuh Paruk, misalnya. Desakan keluarganya untuk menjadi ronggeng, serta tekanan masyarakat terhadap dirinya membuat Srintil pasrah menerima perannya sebagai seorang ronggeng (wanita penghibur) di masyarakatnya. Sikap pasrah atau tunduk inilah yang akhirnya menyebabkan Srintil tak henti-hentinya mengalami pelecehan seksual, karena melakukan tugas-tugas pelayanan kebutuhan seksual lelaki tanpa didasari rasa cinta.

\section{SIMPULAN}

Dari analisis terhadap keempat permaslahan, yakni peran perempuan, permaslaahan perempuan, penyebab permasalahan yang dialami perempuan, dan cara penyelesaian dalam duapuluh novel Indonesia periode 1900-2000, dapat disimpulkan sebagai berikut.

Pertama, peran perempuan yang ditemukan dalam novel-novel yang dikaji adalah peran yang dikembangkan berdasarkan perbedaan jenis kelamin. Pembedaan peran masih sebatas pub- lik dan domestik. Peran perempuan di bidang publik antara lain ditunjukkan dengan keikutsertaan perempuan dalam pergerakan, pendidikan, serta di dunia usaha. Perempuan di bidang domestik terlihat dari peran-peran perempuan sebagai seorang isteri yang bertugas melayani kebutuhan suami dan sebagai seorang ibu yang bertugas merawat anak-anak serta melakukan beberapa pekerjaan rumah tangga.

Kedua, permasalahan yang ditemukan adalah permasalahan yang terikat dengan peran mereka. Persoalan domestik yang ditemukan adalah persoalan psikologis, kebangsaan, konstruksi gender yang merugikan perempuan, kekerasan dalam rumah tangga, politik, serta ketergantungan ekonomi. Persoalan psikologis dan kekerasan dalam rumah tangga adalah bentuk permasalahan yang paling banyak ditemui.

Ketiga, permasalahan-permasalahan yang dialami oleh tokoh perempuan terutama disebabkan oleh adanya perbedaan kebangsaan, kultur budaya masyarakat yang patriarkis sehingga menguntungkan laki-laki dan banyak merugikan perempuan, tafsir agama yang dimanfaatkan untuk menekan kaum perempuan, konstruksi gender yang tidak menempatkan perempuan sejajar dengan laki-laki, hingga politik dan ketergantungan ekonomi.

Keempat, sikap tokoh dalam menghadapi permasalahan terdiri dari tiga hal, pasrah, melakukan perlawanan, serta melakukan ekspaisme atau melarikan diri dari masalah. Belenggu kultur budaya patriarkis dan konstruksi gender yang demikian kuat biasanya menyebabkan tokoh perempuan lebih memilih pasrah atau eskapis. Hanya mereka yang berlatar belakang sosial tinggi, berpendidikan, serta berkarakter lah yang memiliki kemampuan untuk melawannya. 


\section{UCAPAN TERIMA KASIH}

Artikel ini diangkat dari penelitian yang dilaksanakan pada tahun 2009 dengan anggaran DIPA Penelitian Kajian Wanita. Oleh karena itu, ucapan terima kasih disampaikan kepada Lembaga Penelitian UNY yang telah mendanai penyelenggaraan penelitian, seminar proposal dan hasil penelitian. Selanjutnya ucapan terima kasih disampaikan kepada dua reviewer anonim yang telah membaca, mengoreksi dan memberi masukan terhadap artikel ini.

\section{DAFTAR PUSTAKA}

Aminuddin. 2002. Pengantar Apresiasi Karya Sastra. Bandung: Sinar Baru Algensindo.

Blackburn, Susan. 2007. Kongres Perempuan Pertama: Tinjauan Ulang. Jakarta: Yayasan Obor Indonesia.

Brooks, Ann. 2005. Posfeminisme dan Cultural Studies, Sebuah Pengantar Paling Komperehensif. Yogyakarta: Jalasutra.
Budiman, Arief. 1982. Pembagian Kerja secara Seksual: Sebuah Pembahasan Sosiologis tentang Peran Wanita di dalam Masyarakat. Jakarta: Gramedia.

Djajanegara, Soenarjati. 2000. Kritik Sastra Feminis: Sebuah Pengantar. Jakarta: Gramedia.

Lie, Shirley. 2005. Pembebasan Tubuh Perempuan, Gugatan Etis Simeone de Beauvoir terhadap Budaya Patriarkat. Jakarta: Grasindo.

Mills, John Stuart. 1929. The Subjection of Women. London: Longman.

Sugihastuti dan Suharto. 2002. Kritik Sastra Feminis: Teori dan Aplikasinya. Yogyakarta: Pustaka Pelajar.

Teeuw, A. 2003. Sastera dan Ilmu Sastera. Jakarta: Pustaka Jaya.

Wellek dan Warren, Rene dan Austin. 1990. Teori Kesusastraan (diindonesiakan oleh Melani Budianta). Jakarta: Gramedia. 